\title{
THE EFFECT OF HIGH-HEELED FOOTWEAR ON THE INDUCTION OF SELECTED MUSCULOSKELETAL CONDITIONS AND POTENTIAL BENEFICIAL USES IN PROPHYLAXIS AND MANAGEMENT
}

\section{WPŁYW OBUWIA NA OBCASIE NA INDUKCJĘ WYBRANYCH ZMIAN MIĘŚNIOWO- SZKIELETOWYCH ORAZ JAKO FORMA PROFILAKTYKI I UZUPEENIENIE LECZENIA ZACHOWAWCZEGO}

\author{
Gustaw Wójcik ${ }^{1(B, D, E, F)}$ \\ ${ }^{1}$ Pope John Paul II State School of Higher Education in Biała Podlaska, Poland
}

Authors' contribution Wkład autorów: A. Study design/planning zaplanowanie badań B. Data collection/entry zebranie danych C. Data analysis/statistics dane - analiza i statystyki D. Data interpretation interpretacja danych E. Preparation of manuscript przygotowanie artykułu F. Literature analysis/search wyszukiwanie i analiza literatury G. Funds collection zebranie funduszy
Tables: 1

Figures: 5

References: 25

Submitted: 2017 May 1

Accepted: 2017 May 30

\begin{abstract}
Summary
Footwear is, first and foremost, an essential wardrobe component, without which it is difficult to imagine an ordinary working day. High-heeled shoes are mainly worn for aesthetic reasons, and to enhance the slenderness of the female body. Badly fitting footwear can lead to the development of several medical conditions affecting function of the foot as well as the wider musculoskeletal system. Foot deformations correlate highly with the type of footwear being worn. The most commonly occurring foot disorders caused by wearing high heels are: bunions, hammer toe, mallet toe, claw toe, and flat feet. These types of shoes can also cause injuries such as sprains, dislocations and fractures around the ankle joint and in the foot itself. Highheeled footwear may have an effect not only on the foot, but also on the whole limb, including the spine and pelvis, as destructive changes around the foot affect the entire biokinematic chain, and being the first component of this chain they impede movement and negatively impact the function of other joints. Over time, inappropriate function of the foot joints results in dysfunction of other joints located higher, disrupting correct body posture. The aim of this work is to draw the readers' attention to the effects of wearing high-heeled footwear, both the negative and positive, though the latter are extremely rare.
\end{abstract}

Keywords: high-heeled shoes, bunion, hammer toe, mallet toe, claw toe, flat feet, metatarsalgia, impaired body posture

\section{Streszczenie}

Obuwie to przede wszystkim część ubioru współczesnego człowieka, bez którego trudno wyobrazić sobie zwykły dzień pracy. Buty na wysokim obcasie mają stanowić głównie o walorach estetycznych, podkreślając smukłość kobiecego ciała. Nieodpowiednio dobrane obuwie może stać się przyczyną wielu stanów chorobowych bezpośrednio przekładających się na funkcję stóp jak i szerzej pojętego układu mięśniowo-szkieletowego. Deformacje stóp mają silny związek z rodzajem noszonego obuwia. Najczéściej spotykane zniekształcenia stóp wygenerowane przy pomocy butów na wysokim obcasie to: paluch koślawy, palce młotkowate, palce młoteczkowate, palce szponiaste i stopa płasko-koślawa. Buty takie mogą stać się też przyczyną urazów, do których zaliczyć należy skręcenia, zwichnięcia czy złamania w obrębie stawu skokowego jak i samej stopy. Obuwie na obcasie może mieć wpływ nie tylko na samą stopę lecz na całą kończynę dolną z kręgosłupem i miednicą włącznie, gdyż rozpoczynając zmiany destrukcyjne stawów na obwodzie stopy oddziałują na cały łańcuch biokinematyczny, a będąc pierwszymi z tego łańcucha utrudniają poruszanie się i wpływają na funkcjonowanie pozostałych stawów. Ich niewłaściwa praca z biegiem czasu skutkuje dysfunkcja stawów położonych powyżej i zaburza prawidłową postawę ciała. Celem pracy jest zwrócenie uwagi czytelników na skutki noszenia obuwia na obcasie, zarówno te negatywne jak i te pozytywne, choć te drugie, występują dużo rzadziej.

Słowa kluczowe: buty na obcasie, paluch koślawy, palce młotkowate, palce młoteczkowate, palce szponiaste, stopa płasko-koślawa, metatarsalgia, zaburzenia postawy ciała

Wójcik G. The effect of high-heeled footwear on the induction of selected musculoskeletal conditions and potential beneficial uses in prophylaxis and management. Health Prob Civil. 2019; 13(3): 209-216. https://doi.org/10.5114/hpc.2018.80227

Address for correspondence / Adres korespondencyjny: Gustaw Wójcik, Institute of Physical Education and Physiotherapy, Faculty of Health and Social Sciences, Pope John Paul II State School of Higher Education, Sidorska 95/97, 21-500 Biała Podlaska, Poland, e-mail: gustaww@tlen.pl, phone: +48 508247049 ORCID: Gustaw Wójcik https://orcid.org/0000-0001-5005-9711

Copyright: ( P Pope John Paul II State School of Higher Education in Biała Podlaska, Gustaw Wójcik. This is an Open Access journal, all articles are distributed under the terms of the Creative Commons Attribution-NonCommercial-ShareAlike 4.0 International (CC BY-NC-SA 4.0) License (http://creativecommons.org/licenses/ by-nc-sa/4.0/), allowing third parties to copy and redistribute the material in any medium or format and to remix, transform, and build upon the material, provided the original work is properly cited and states its license. 


\section{Introduction}

Primitive humans moved around barefoot, but they were acutely aware that their chances of survival were highly dependent on environmental factors, including healthy and functional feet. Diseased and injured limbs caused individuals to become dependent on the help of others. Moving around barefoot through rough terrain often caused foot injuries, and efforts were made to try to protect them - leading to the creation of the first shoes. Neolithic shoes found on the remains of the "Tyrolean Iceman", who was discovered in the Alps, were made out of bear skin filled with straw and tied together with string - these shoes already provided some protection and allowed the man to cover large distances [1].

In ancient and medieval times, shoes were already being created using completely different technologies, which allowed for the joining of a sole with an upper fragment of the shoe, providing protection for the foot and the lower calf. For centuries, wearing shoes was a sign of prestige, a privilege of free and rich individuals. Slaves and the poor continued to walk barefoot. Until the end of the $16^{\text {th }}$ century, the left shoe was practically indistinguishable from the right, and they could be worn interchangeably. In addition, these kinds of shoes were longer than the foot itself, which is a form of universalism, as they fit both long and short feet. Their only distinguishing factor was in their coloration, as the prevailing fashion dictated that they should contrast with the trouser legs being worn [2]. In the $17^{\text {th }}$ century, heels began to be added to flat shoes, causing the left shoe to become different from the right. This arose from the fact that shoes were becoming more fitted, and elevating the back of the foot affected the shape of the front half of the shoe, directing its point towards the inner edge of the foot. The addition of heels was necessary at the time to keep the foot away from dirty streets. It is worth adding that at the time, men's shoes were more decorative and refined [2, 3]. It was only in the $20^{\text {th }}$ century, with the rise of industrialisation, that shoes became relatively cheap and easily accessible to everyone. In many cases, the shoes whose primary role was to protect the feet began to have negative effects, causing deformities in the lower limbs, pelvis and in the musculoskeletal system.

Most deformations around the foot begin with an initial inflammation of the synovial bursa, which is caused by maintaining a joint in an unnatural, forced position. Bursitis causes significant pain and discomfort, especially during walking. When the synovial bursa are exposed to excessive pressure, they begin to secrete synovial fluid in inappropriate amounts, leading to their inflammation and enlargement [4]. The newly formed structures disrupt correct anatomical relationships, initiating the changes leading to deformation. Inflammation of the synovial bursa impedes the movement of ligaments and muscles, and consequently leads to motor dysfunction. Individuals particularly at risk of developing bursitis are those who force their body to function in an unnatural position [5]. A perfect example of this are high-heeled shoes. Despite their undeniable aesthetic appeal, this type of footwear unfortunately also has a high probability of causing injury, however from the perspective of time, an injury may become a constructive experience that may change wardrobe preferences.

Many modern women cannot imagine a life without high-heeled shoes which, despite the aesthetic values, have a relatively strong effect on the feet, giving rise to deformities. The higher the heel, the easier it is for the foot to slip down in it, and the toes put pressure on the tip of the shoe, leaving little space for themselves, and leading to their unnatural positioning. Long-term, forced positioning of the foot in a high-heeled shoe impacts on all the structures of the locomotor system surrounding the foot, including: ligaments, joint capsules, muscles, and tendons, positioning the joints incorrectly (Figure 1). Tight shoes not only cause deformities, but also constrict various tissues, disrupting vascular flow, which in some cases may lead to atrophy. Unfortunately, unergonomic footwear causes not only degeneration, but also adaptive changes in the entire peripheral and axial musculoskeletal system, which is often a contributing factor to many diseases and syndromes.
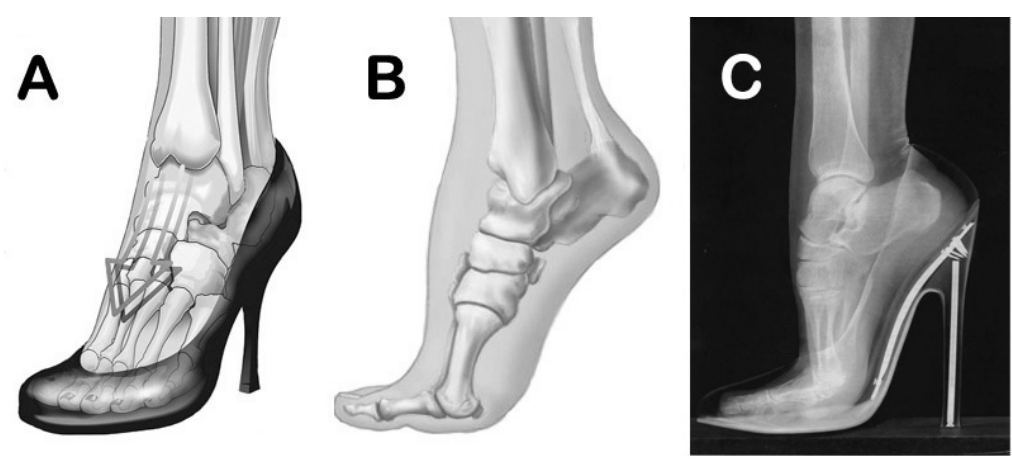

Figure 1. The effects of high-heeled footwear on skeletal and joint structures of the foot. A - slipping of the foot restricts space for the toes. B - vertical positioning of the foot reduces the supporting surface area and disrupts the mechanics of the MTP joints. C - X-ray image of a foot in a high-heeled shoe depicts the tarsal and metatarsal bones as an elongation of the axis of the lower leg Source: the author 


\section{Aim of the work}

The aim of this work is to present selected foot deformities caused by wearing high-heeled footwear, which is important from the point of view of basic healthcare providers, orthopaedists, neurologists, physiotherapists and other medical specialisations, including within public health. An aim of this work is to additionally draw attention to the fact that in some cases, high-heeled footwear can also be used to help manage certain medical conditions.

\section{Bunions}

A further foot deformity resulting from the use of high-heeled shoes with narrow points are bunions. A high heel (over $6 \mathrm{~cm}$ ) causes the forefoot to be subjected to greater strain, while the narrow point aligns the toes, and especially the big toe, in an incorrect position [6]. These factors cause a worsening of the deformity, which constitutes not only a cosmetic problem, but a much more serious partial lateral dislocation of the big toe and its associated MTP joint, moving it towards the second toe. This condition is associated with a limited range of motion and increased pain, especially during attempted movement, as this is associated with an unfavourable change in the biomechanics of walking [7]. At the medial side of the foot, at the MTP 1 joint, a painful enlargement is formed, deforming the outline of the foot (Figure 2). It is formed by a protruding first metatarsal bone and an enlarged synovial bursa of the big toe, which normally protect the MTP 1 joint from chronic compression.

Predisposing factors for bunions include flat feet (due to increased strain on the forefoot), contraction of the Achilles tendon (forced by plantar flexion of the foot), and instability of the ankle joint.

Bunions are the most common foot deformity, which is present in about $30 \%$ of adults [8]. The incidence of this deformity increases with age. Prusinowska et al. [9] found that the incidence is 3\% in individuals aged 15$30,9 \%$ in those aged $31-60$, and $16 \%$ in individuals above 60 years of age.

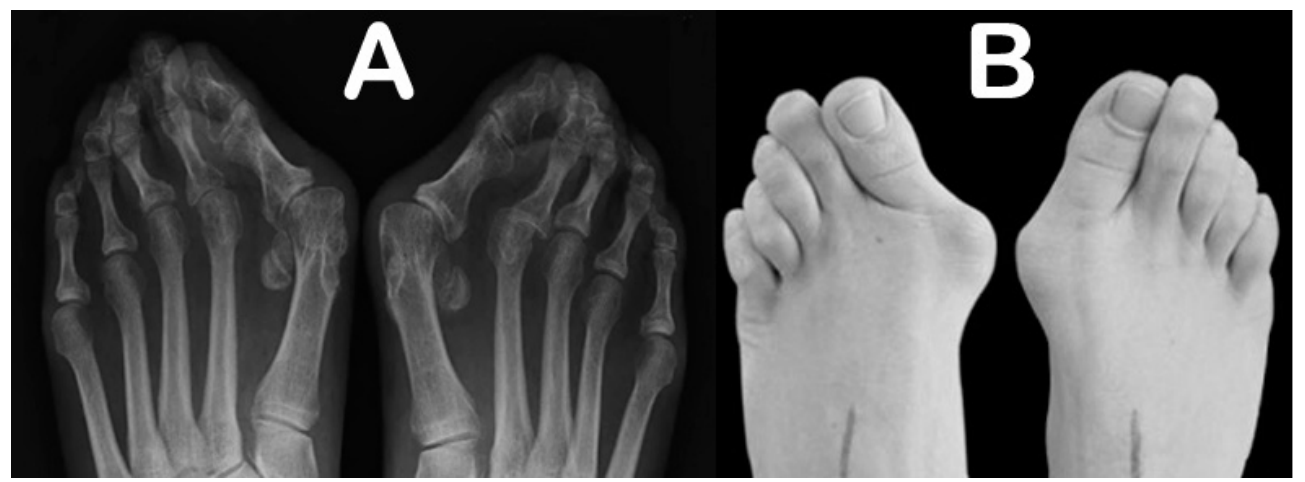

Figure 2. Bunions. A - X-ray image of feet in the AP view. B - clinical image of deformed feet Source: the author

\section{Hammer toe}

Hammer toe is a common foot deformity caused by the wearing of high-heeled shoes ( $>6 \mathrm{~cm})$, meaning that they are caused by the transfer of body weight onto the front part of the foot. The high heel pushes the foot downwards, pressing the toes against the tip of the toe, increasing pressure and causing dorsal flexion of the $2^{\text {nd }}$ to $5^{\text {th }}$ toes (most commonly the second toe, as it is the longest). Because of this, these deformities occur in the sagittal plane (Figures 3 and 4). Footwear that narrows in the direction of the toes causes the forefoot to become narrower, and the lack of space causes the smaller toes to be pushed into a dorsal flexion at the MTP joints. These deformities are very common and can take the form of small, asymptomatic changes all the way to large ones, which significantly limit the capabilities of the patient. Initial deformation occurs in the PIP joints of the foot, while a secondary element of the deformity is a slight hyperextension in the MTP join [6]. The development of hammer toes is also promoted by bunions, which cause the remaining toes to be improperly aligned. The lateral movement of the big toe into the space of the neighbouring toe causes it to flex dorsally. Initially hammer toes may have limited mobility, but with disease progression they become rigid. In this condition, disproportions are formed between the muscles responsible for bending and straightening the toes, and their impaired length means that a toe that is bent in one position cannot be straightened even when its extensor muscle is tensed, 
leading to flexion contracture. Ultimately, the muscles of the toes lose the ability to straighten the toe, even when this movement is not limited by the footwear being worn [10].

Hammer toes frequently co-occur with bunions and are found in about $30 \%$ of the adult population aged over 65 years [11].

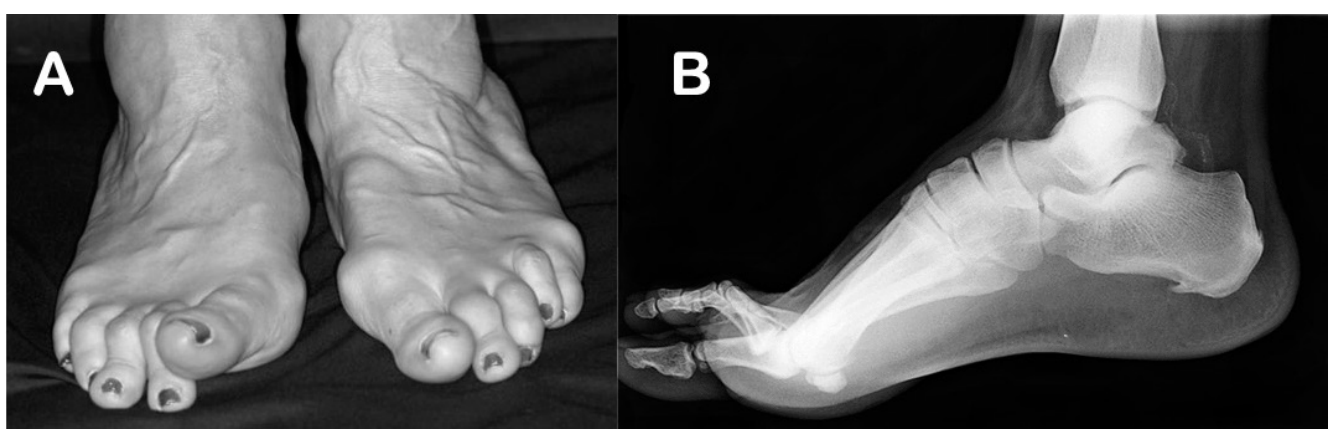

Figure 3. Hammer toes. A - clinical picture of hammer-like positioning of the $2^{\text {nd }}, 3^{\text {rd }}$ and $4^{\text {th }}$ toes. B - Hammer toes in an X-ray (side view)

Source: the author

\section{Mallet toe}

Mallet toe can be a result of wearing tight footwear or high-heeled shoes, which causes a sliding of the foot in the shoe towards the toes, which is associated with a deformation of the forefoot and excessive plantar flexion of the $2^{\text {nd }}$ to $5^{\text {th }}$ toes in the DIP joints, while preserving the longitudinal axis in the MTP and PIP joints (Figure 4) [12].

Mallet toes should not be confused with hammer toes, which are a deformity consisting of bending in the PIP joint and hyperextension in the MTP joint.

\section{Claw toe}

Claw toe resembles mallet toe, and in both cases the deformity affects the $2^{\text {nd }}$ to $5^{\text {th }}$ toes. In claw toe, hyperextension of the MTP joint always occurs, with additional flexion in the PIP and DIP joints (Figure 4). Claw toe is the kind of toe alignment that usually gives rise to blisters, causing pain and discomfort. Due to the bending, the dorsal side of the toe is prone to rubbing and blistering, similarly to the tip of the toes, which is being pressed against the sole of the shoe. Claw toes are classified based on the mobility of the toe joints. Two types exist - elastic and rigid. Elastic claw toes are able to move. This type of deformity can be manually straightened. Rigid claw toes cannot move. Movement of the toes is very limited and can be very painful [12].

Every fifth deformity of the forefoot $(20 \%)$ is a result of developing claw toe [13]. These deformities occur very commonly and can take the form of small, asymptomatic changes all the way to large deformities significantly limiting the abilities of the patient. With time, claw toes lose their normal range of motion and become a permanent deformity.

Table 1. Types of forefoot deformity

\begin{tabular}{|c|c|}
\hline Type of deformity & Location of deformities \\
\hline Hammer toe & $\begin{array}{c}\text { Plantar flexion in the proximal interphalangeal joint which may be accompanied by } \\
\text { hyperextension in the metatarsophalangeal joint }\end{array}$ \\
\hline Mallet toe & $\begin{array}{c}\text { Plantar flexion in the distal interphalangeal joint without changes in the metatarsopha- } \\
\text { langeal joints. }\end{array}$ \\
\hline Claw toe & $\begin{array}{c}\text { Plantar flexion in both interphalangeal joints with a simultaneous dorsal flexion in the } \\
\text { metatarsophalangeal joints. }\end{array}$ \\
\hline
\end{tabular}



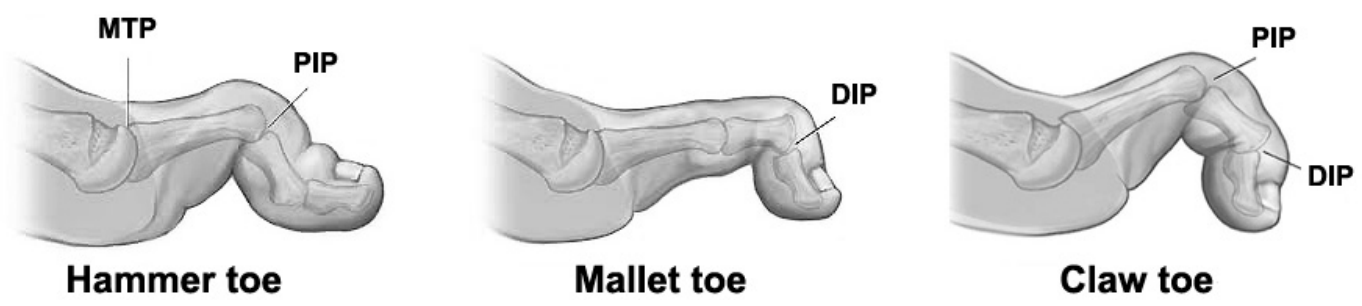

Figure 4. Types of forefoot deformities classified by the location of the deformity

\section{Flat feet}

Flat feet are the most common foot deformity in humans. This deformity is caused by long-term loading of the foot with simultaneous weakening of ligaments and muscles, leading to their extension. Improperly fitted and uncomfortable footwear, as well as overweight and its associated excessive pressure on the feet can also cause the weakening of the physiological arches of the foot [14].

The correctly arched foot has three physiological points of support, which are: the sole, the head of the first metatarsal bone and the head of the fifth metatarsal bone. This support of the foot is possible when the physiological arches, or the longitudinal and transverse arches, are preserved. In flat feet, at least one of these arches is lowered or completely absent. The foot in a high-heeled shoe has a limited support area, which is practically confined to the forefoot. Excessive loading of this region causes the metatarsal bones to become spread apart and the arch to become flattened, leading to the body weight to be transferred to the second, third and fourth metatarsal bones. This mechanism allows for the formation of transverse flat feet [15].

As mentioned previously, wearing high-heeled footwear causes a reduction in the area of the supporting surface, leading to an increase in the loading on the longitudinal arch, causing it to be lowered and increasing the shared area between the sole of the foot and the surface.

When flat feet develop, they often lead to other deformities, such as hammer toes and bunions [16].

In children, flat feet occur quite frequently and are described as physiological, since with reaching adulthood the problem often subsides by itself. Within the young adult population, the incidence of flat feet is estimated to be around $17 \%[14]$.

When flat feet are diagnosed, the use of high-heeled shoes should be stopped (recommended heel height $<3 \mathrm{~cm}$ ), and footwear should contain insoles that support the normal curvature of the arches. Shoes with wide points predispose towards the development of flat feet.

\section{Injuries of the ankle joint}

The ankle joint is a complex mechanism which is capable of a wide range of motion: flexion, extension, inversion, eversion and a combination of these movements, and it is therefore prone to injury. Ankle injuries are fairly common in women using high-heeled shoes. The higher the heel, the greater the risk of injury. A range of predisposing factors contribute to ankle injuries, including a reduction in the supporting base area, moving of the centre of gravity upwards and forwards, weakening of the muscle-joint-ligament apparatus, as well as defects caused by varus or valgus gait. The most common ankle injuries are sprains, resulting from excessive supination. The foot is rotated too far outward, which affects the destabilisation of the step and incorrect mechanics of the entire lower limb. A sprain is the mildest forms of injury, which in principle is limited to a twisting of the joint capsule and a stretching of ligaments without the loss of contact between the joint surfaces. Ankle sprains most commonly occur in women above the age of 30 . Following ankle sprains, the fibula may become inappropriately displaced distally and remain in this position. This leads to an excessive stretch of the biceps femoris muscle, which reflexively leads to an increase in its muscle tone. The result of this is increased pulling of the ischium in the direction of backwards rotation of the pelvis, which can lead to irritation of the sacroiliac joint [17].

Other, equally serious consequences can result from dislocation, leading to the bursting of the joint capsule and the ligaments stabilising the joint. Dislocation most commonly happens during inversion, when damage occurs to the lateral ligaments of the ankle joint: the anterior and posterior talofibular ligaments and the calcaneofibular ligaments [18]. During eversion, damage occurs to the deltoid ligaments. Dislocation leads to bloody haematomas, indicating damage to blood vessels. Individuals who have had previous dislocations have an increased risk of suffering another sprain or dislocation, which relates to the instability formed earlier. Individuals with weakened muscles in the lower leg, especially the peroneus muscles are also at higher risk of lateral dislocations [19]. 
High ankle sprains refer to the tearing of the ankle syndesmosis, connecting the tibia and fibula to the ligaments connecting the lower leg to the foot. These injuries are significantly less common than the typical lateral ankle sprains, however they are often accompanied by fractures in the bones of the ankle.

Ankle instability in individuals using high-heeled shoes can have even more serious consequences in the form of single- or double-ankle fractures, which are also related to damage to the joint-ligament apparatus.

The rate of occurrence of fractures in the region of the ankle joint in the general population can reach even $15 \%$, of which the vast majority related to the use of high-heeled footwear. The frequency of these injuries increases with higher walking speed and elongated step length [20].

\section{Disorders of posture and effects on the nervous system}

In unhindered conditions during free standing, the hip knee joints are extended, and the angle formed by the plane of the foot with the axis of the lower leg is around $90^{\circ}$. This angle changes during different phases of gait, especially in the stance phase - it is the smallest when the heel contacts the walking surface, and the largest when the toes are lifted off the surface. Wearing high-heeled footwear causes an increase in the angle between the longitudinal axes of the foot and the lower leg both during free standing as well as during all phases of gait. This has a strong effect in moving the centre of gravity forward, which imposes certain compensatory mechanisms on the musculoskeletal system, allowing for the maintenance of a stable posture [6, 21]. Higher tension is placed on the posterior structures of the calf, which are responsible for bending the ankle and anterior thighs, which in turn bend the hip joints. Changes in muscle tension play their own role in forward tilting of the pelvis and a worsening of lumbar hyperlordosis, which causes overloading of the spine and accelerates degenerative changes in the posterior spinal column (Figure 5).

High-heeled shoes can be used as a form of medical management in patients suffering from ankylosing spondylitis (AS). During the development of AS, patients adopt a characteristic "skier position", which is highly detrimental to both body posture and gait [22]. Using high-heeled shoes has a corrective effect on spinal extension, but it should be remembered that the high heels cannot cause a compensatory bending in the knee joints. Use of this kind of footwear (heel height $2-4 \mathrm{~cm}$ ) should take place in the early stages of the disease, where degenerative changes in the axial musculoskeletal system have not yet been consolidated. Consistent wearing of high-heeled footwear will not protect the patient from joint stiffening, but will allow this ossification to happen when the spine is in an extended position, leading to increased quality of life, owing for example to higher lung capacity and greater range of visibility [23].

During clinical examination of patients with suspected sciatica, attention is paid to the way the patient moves as well as the footwear that the patient is wearing at the appointment. In female patients wearing high-heeled shoes on a daily basis, the problem of sciatica seems obvious. But can we be sure? Indeed, high-heeled footwear causes the user to experience heightened tension in the muscles of the spine, allowing the patient to close the vicious circle of the chain of pain, but this mechanism occurs most often in individuals who rarely use this type of footwear [24]. In individuals who use it often, these muscles are well trained and stabilise the spine with less effort. In the question of provoking pain, high heeled shoes cause the peroneal nerve, one of the branches of the sciatic nerve, to have an unhindered course, where it is not irritated by tension. In a patient who always walks in high-heeled footwear, wearing flat shoes will cause dorsal flexion of the foot, causing a tensing of the peroneal nerve, leading to pain. Therefore when assessing neuropathic pain in patients who move around on high-heeled footwear, the frequency of their use should always be taken into account, as it is key to a reliable diagnosis and appropriate therapeutic proceedings. 


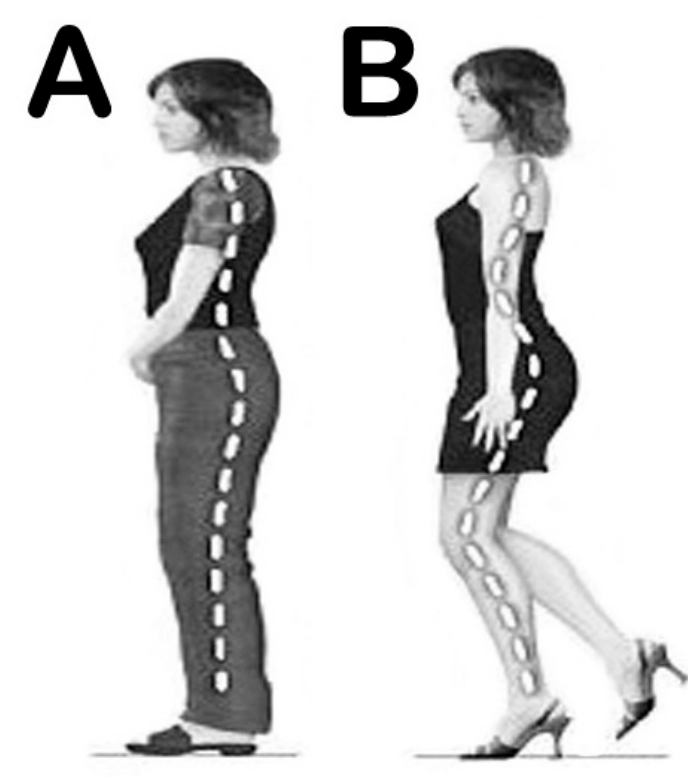

Figure 5. Changes to the curvature of the spine and tilting of the pelvis while wearing shoes with varying heel height. A - flat shoes cause a neutral positioning of the pelvis and correct lumbar lordosis. B - high-heeled shoes cause a forward tilt of the pelvis and lumbar hyperlordosis, which can be the cause for degenerative changes in the spine. A lowering of the center of gravity also disrupts the muscle synergy of flexor and extensor muscles around the lower limbs

Source: the author

\section{Thromboembolism}

High-heeled shoes cause the muscle tension in the lower limb to be much higher than during the use of flat shoes, which significantly slows down peripheral blood flow and promotes the development of chronic venous insufficiency. High-heeled shoes are mostly worn by young women of reproductive age, who may be increasing their risk of thromboembolism through the use of hormonal contraceptives [25]. This risk is significantly increased in women whose work involves long-term standing, for example hostesses and check-out clerks. A decidedly positive effect is achieved by women who move dynamically in stilettos, alternately tensing and flexing the calf muscle, therefore preventing blood congestion in the lower limbs and promoting circulatory mechanisms. It is also worth highlighting that women who move around in high-heeled shoes on a daily basis have slimmer calves, which is a result of high energy requirements of these muscles, and burning of fat found in their vicinity.

\section{Conclusions}

Shoes with heels of variable height are a widespread element of daily wardrobes of modern women. A high proportion of ladies wearing high-heeled shoes experience pain and discomfort around the joints of the lower limb, which become worsened around the feet. High-heeled footwear is in large part responsible for pain in the lumbar section of the spine and changes in the axial positioning of the pelvis, which can result in impaired gait. Individuals using high-heeled shoes are more prone to ankle injury than those who wear flat shoes. High-heeled shoes can also be linked to circulatory disorders which manifest as distal swelling in the lower limb. This does not mean that high-heeled shoes only have negative effects on women's health. In some cases, they can be used as a form of medical management, e.g. over the course of AS.

\section{Selected abbreviations}

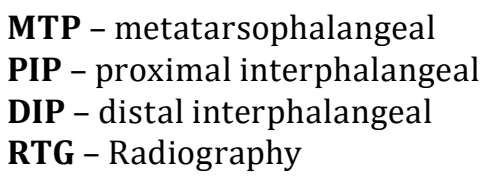




\section{References:}

1. Püntener AG, Moss S. Otzi, the iceman and his leather clothes. Chimia (Aarau). 2010; 64(5): 315-20. https://doi.org/10.2533/chimia.2010.315

2. Asimov I. Isaac Asimov's book of facts. New York: Wings Books; 1979. p. 113-114.

3. History of footwear [Internet]. [cited 2016 Oct 6]. Available from: www.footwearhistory.com

4. Damiano J. Forefoot pain. Rev Prat. 2010; 60(3): 345-52.

5. Ashman CJ, Klecker RJ, Yu JS. Forefoot pain involving the metatarsal region: differential diagnosis with MR imaging. Radiographics. 2001; 21(6): 1425-40. https://doi.org/10.1148/radiographics.21.6.g01nv071425

6. Cong Y, Cheung JT, Leung AK, Zhang M. Effect of heel height on in-shoe localized triaxial stresses. J Biomech. 2011; 44(12): 2267-72. https://doi.org/10.1016/j.jbiomech.2011.05.036

7. Hart ES, deAsla RJ, Grottkau BE. Current concepts in the treatment of hallux valgus. Orthop Nurs. 2008; 27(5): 274-80. https://doi.org/10.1097/01.NOR.0000337276.17552.1f

8. Lowery NJ, Wukich DK. Adolescent hallux valgus: evaluation and treatment. Operative Techniques in Orthopaedics. 2009; 19(1): 52-57. https://doi.org/10.1053/j.oto.2009.07.001

9. Prusinowska A, Maciejewski W, Turski P, Cichocki T, Małdyk P, Księżopolska-Orłowska K. [Hallux valgus in rheumatoid foot: surgical treatment and rehabilitation]. Reumatologia. 2011; 49(2): 90-95 (in Polish).

10. Abousayed M, Kwon JY. Hallux claw toe. Foot Ankle Clin. 2014; 19(1): 59-63. https://doi.org/10.1016/j.fcl.2013.11.001

11. Dunn JE, Link CL, Felson DT, Crincoli MG, Keysor JJ, McKinlay JB. Prevalence of foot and ankle conditions in a multiethnic community sample of older adults. Am J Epidemiol. 2004; 159: 491-498. https://doi.org/10.1093/aje/kwh071

12. DiPreta JA. Metatarsalgia, lesser toe deformities, and associated disorders of the forefoot. Med Clin North Am. 2014; 98(2): 233-51. https://doi.org/10.1016/j.mcna.2013.10.003

13. Harrasser N, Toepfer A, Lenze F, Pohlig F, von Eisenhart-Rothe R. Lesser toe deformities: what the general practitioner should know. MMW Fortschr Med. 2015; 157(11): 43-4. https://doi.org/10.1007/s15006-015-3217-9

14. Chianea H, Derkenne C. A cause of unilateral flat foot. Presse Med. 2016; 45(4 Pt 1): 463-4. https://doi.org/10.1016/j.lpm.2016.01.002

15. Kim MK. Foot pressure analysis of adults with flat and normal feet at different gait speeds on an ascending slope. J Phys Ther Sci. 2015; 27(12): 3767-9. https://doi.org/10.1589/jpts.27.3767

16. Sheikh Taha AM, Feldman DS. Painful flexible flatfoot. Foot Ankle Clin. 2015; 20(4): 693-704. https://doi.org/10.1016/j.fcl.2015.07.011

17. Wappelhorst U, Kittelmann A, Robbelen C. [Handbook and workbook functional anatomy]. Munchen: Elsevier/Urban\&Fisher; 2006 (in German).

18. McGovern RP, Martin RL. Managing ankle ligament sprains and tears: current opinion. Open Access J Sports Med. 2016; (7): 33-42.

19. Mengiardi B, Pinto C, Zanetti M. Spring ligament complex and posterior tibial tendon: MR anatomy and findings in acquired adult flatfoot deformity. Semin Musculoskelet Radiol. 2016; 20(1): 104-15. https://doi.org/10.1055/s-0036-1580616

20. Greaser MC. Foot and ankle stress fractures in athletes. Orthop Clin North Am. 2016; 47(4): 809-22. https://doi.org/10.1016/j.ocl.2016.05.016

21. Semple R, Murley GS, Woodburn J, Turner DE. Tibialis posterior in health and disease: a review of structure and function with specific reference to electromyographic studies. J Foot Ankle Res. 2009; $19(2): 24$. https://doi.org/10.1186/1757-1146-2-24

22. Kuncewicz E, Gajewska E, Sobieska M, Atarowska M, Samborski W. [Physiotherapy in ankylosing spondylitis]. Balneologia Polska. 2006; 4: 207-210 (in Polish).

23. Ahsan T, Erum U, Jabeen R, Khowaja D. Ankylosing Spondylitis: a rheumatology clinic experience. Pak J Med Sci. 2016; 32(2): 365-8.

24. Mika A, Oleksy $Ł$, Mika P, Marchewka A, Clark BC. The effect of walking in high and low-heel shoes on erector spinae activity and pelvis kinematics during gait. Am J Phys Med Rehabil. 2012; 91(5): 425-34. https://doi.org/10.1097/PHM.0b013e3182465e57

25. Menczekalski B, Czyżyk A, Katulski K, Maciejewska-Jeske M. [Safety profile of hormonal contraception in premenopause]. Przegląd Menopauzalny. 2013; 1: 15-22 (in Polish). 